\title{
Modulating Efficiency of $y$-Irradiated Rosemary in Improving the Hepatic Antioxidant Status of Ethanol Administrated Rats
}

\author{
R. G. Hamzaa*, A. N. El Shahat and H.M.S. Mekawey
}

Food Irradiation Research Department, National Centre for Radiation Research and Technology (NCRRT), Atomic Energy Authority, Nasr City, Cairo, Egypt

\begin{abstract}
Alcoholic liver disease represents a spectrum of clinical illness and morphological changes such as hepatic inflammation and necrosis (alcoholic hepatitis). Among natural antioxidants, rosemary contains several antioxidant oil and phenolic components that exhibit hepatoprotective effect. This study aimed to investigate the antioxidant effect of dietary supplementation with $y$-irradiated rosemary in ethanol induced liver injury in rats. Rosemary essential oil was analyzed by gas chromatography/mass spectrometry (GC/MS). The results of biological study revealed that dietary supplementation of either raw or $\mathrm{y}$-irradiated rosemary following ethanol administration exerts remarkable modulating effect by reducing the level of total bilirubin, the activity of transaminases, gamma glutamyl transferase and serum alkaline phosphatase, decreasing the concentration of some lipid contents, malondialdehyde and xanthine oxidase activity. Also, supplementation of dietary rosemary resulted in elevation of high density lipoprotein level, reduced glutathione content and enhances the activity of xanthine oxidase dehydrogenase, superoxide dismutase and catalase. Thus, gamma-irradiated rosemary could be incorporated to the diet as a nutritional supplement, to augment the liver's defences against oxidative stress.
\end{abstract}

Keywords: Liver diseases; Rosemary; Essential oil; Gammairradiation; Antioxidants

\section{Introduction}

Liver is the first organ to metabolize all foreign compounds and hence it is susceptible to many different diseases [1]. Alcohol administration is one of the most common causes of chronic liver disease in the world and it was found that alcohol affects the liver, through not only nutritional disturbances but also its direct toxicity, because its predominant metabolism in the liver is associated with oxidation-reduction changes and oxidative stress [2]. The body's natural defenses against free radicals (e.g. antioxidants) are inhibited by alcohol consumption resulting in the increasing of liver damage $[3,4]$.

There has been a great deal of interest in the role of complementary and alternative medicines for the treatment of various acute and chronic diseases [4]. Herbal medicine is based on the premise that plants contain natural substances that can promote health and alleviate illness [5].

One of these herbs is Rosemary or Rosmarinus officinalis L. (Labiatae) which is an evergreen perennial shrub grown in many parts of the world. It has been used as medicinal plants in folk medicine, but Rosmarinus itself was used for asthma, bronchitis, cold, flu, digestive, anaemia, hypertension, insomnia, labyrinthitis, sluggishness memory, tachycardia, vitiligo, for high cholesterol and diabetes disease [69]. Rosemary contains caffeic acid, carnasol, rosmaridiphenol and rosmarinic acid, all of which are potent antioxidants as well as antiinflammatory agents. Due to its antioxidants, rosemary can help prevent cataracts and the natural acids present in rosemary help in protecting the body's cells and DNA from free radical damage. It is also a good source of antioxidant vitamin E (alpha tocopherol) and other important antioxidants [10]. Moreover, the volatile oils in rosemary also help reduce inflammation that contributes to liver and heart disease [11].

Especially during picking, processing and packing, rosemary is susceptible to contamination by pathogenic microorganisms [12]. Gamma radiation is a highly effective means of inhibiting the growth of undesirable microbes and avoiding the occurrence of food-transmitted diseases. This is substantiated by the fact that an increasing number of countries have adopted irradiation as a way to ensure the hygienic quality of dehydrated foods [13]. The international safe dose clearance is up to $10 \mathrm{kGy}$, though some countries, including Argentina, have increased this level to $30 \mathrm{kGy}$ without any harmful effects being observed [14]. Also, the effect of irradiation on some of the compounds responsible for antioxidant activity in rosemary has been reported by Koseki et al. [15], Calucci et al. [16] and El-Beltagi et al. [17].

The objective of the study is therefore to evaluate the efficiency of dietary supplementation with raw and $\gamma$-irradiated rosemary in improving the hepatic antioxidant status of ethanol administrated rats.

\section{Material and Methods}

\section{Materials}

Rosemary (Rosmarinus officinalis L.) powder and standard commercial rodent diet were purchased from local herbal market (Cairo, Egypt), while ethanol was purchased from Sigma Company.

\section{Gamma irradiation process}

The samples of dry rosemary powder were transferred into polyethylene bags and treated with $10 \mathrm{kGy}$ of gamma rays, using a $60 \mathrm{Co}$ source at a dose rate of $4.70 \mathrm{kGy} / \mathrm{h}$ at the National Centre for Radiation Research and Technology (NCRRT), Egypt.

*Corresponding author: Refaat Galal Hamzaa, Department of Food Irradiation National Centre for Radiation Research and Technology (NCRRT), Atomic Energy Authority, Nasr City, Cairo, Egypt, E-mail: refaatghamza@yahoo.com

Received October 22, 2012; Accepted November 19, 2012; Published Novembe 22, 2012

Citation: Hamzaa RG, El Shahat AN, Mekawey HMS. (2012) Modulating Efficiency of $y$-Irradiated Rosemary in Improving the Hepatic Antioxidant Status of Ethanol Administrated Rats. Biochem Anal Biochem 1:124. doi:10.4172/2161 1009.1000124

Copyright: @ 2012 Hamzaa RG, et al. This is an open-access article distributed under the terms of the Creative Commons Attribution License, which permits unrestricted use, distribution, and reproduction in any medium, provided the original author and source are credited. 
Citation: Hamzaa RG, El Shahat AN, Mekawey HMS. (2012) Modulating Efficiency of Y-Irradiated Rosemary in Improving the Hepatic Antioxidant Status of Ethanol Administrated Rats. Biochem Anal Biochem 1:124. doi:10.4172/2161-1009.1000124

Page 2 of 6

\section{GC-MS analysis of rosemary essential oil}

Extraction of essential oil: The essential oils of rosemary were obtained by water distillation in a glass apparatus for 3 hours. The separated volatile oils were dried over anhydrous sodium sulphate before hold glass bottles at $-20^{\circ} \mathrm{C}$ according to Guenther [18].

Separation and identification of chemical components of the essential oil: Separation and identification of essential oil components were performed by using Gas chromatography instrument, Model Hewlett-Packard- MS (5970) series II at the Agriculture Research Centre, Giza, Egypt. Condition analysis are as follows: Column-30 m hp Methyl silicon $0.1 \mathrm{~mm}$; Temperature: Initial $60^{\circ} \mathrm{C}$; Rate: $3^{\circ} \mathrm{C} / \mathrm{min}$ up to $240^{\circ} \mathrm{C}$; Carrier gas: Helium $1.0 \mathrm{ml} / \mathrm{min}$; Injection port; Temperature: $250^{\circ} \mathrm{C}$; Detector temperature: $270^{\circ} \mathrm{C}$; Integration: By using HP software Data; Injection volume: $0.3 \mathrm{ml}$. The isolated peaks were identified by matching with data from the library of mass spectra and compared to those of authentic compounds and published data [19]. Quantitative determination was carried out based on peak area integration.

\section{Animals}

The experiments were conducted on male albino rats $(140 \pm 20 \mathrm{~g})$. The animals were housed under conditions of controlled temperature $\left(30 \pm 2^{\circ} \mathrm{C}\right)$ with natural light. Food and water were provided ad-libitum.

\section{Study design}

The animal were randomly divided into 4 groups, each consisted of 7 rats.

Group I: rats were fed on balanced diet for 8 weeks, served as control,

Group II: rats were fed on balanced diet for 8 weeks and received daily oral dose of $20 \%(\mathrm{v} / \mathrm{v})$ ethanol $5 \mathrm{ml} / 100 \mathrm{~g}$ body weight daily for four weeks [4].

Group III: rats received daily oral dose of $20 \%$ (v/v) ethanol (5 $\mathrm{ml} / 100 \mathrm{~g}$ B.wt./day) for 4 weeks followed by dietary raw rosemary $(1 \% \mathrm{~W} / \mathrm{W})$ for 4 weeks.

Group IV: rats received daily oral dose of $20 \%(\mathrm{v} / \mathrm{v})$ ethanol (5 $\mathrm{ml} / 100 \mathrm{~g}$ B.wt./day) for 4 weeks followed by dietary irradiated rosemary $(1 \% \mathrm{~W} / \mathrm{W})$ for 4 weeks.

At the end of the experiment, animals from each group were sacrificed $24 \mathrm{hrs}$ post the last dose of treatment. Blood samples were collected though heart puncture after light anaesthesia and allowed to coagulate and centrifuged to obtain serum for biochemical analysis. Also, liver tissue was removed for biochemical investigation.

\section{Biochemical analysis}

The activity of serum aspartate transaminase (AST) and alanine transaminase (ALT) was estimated according to Reitman and Frankel [20], serum gamma glutamyl transferase (GGT) was assessed according to Rosalk [21] as well as serum alkaline phosphatase activity (ALP) was assessed according to Kind and King [22]. Total bilirubin was analyzed using the method reported by Malloy and Evelyn [23]. In addition, total cholesterol (TC), triglycerides (TG) and high-density lipoproteincholesterol (HDL-C) were determined according to procedure described by Allain et al. [24], Fossati and Prencipe [25] and Demacker et al. [26], respectively, while low-density lipoprotein cholesterol and very low-density lipoprotein-cholesterol were evaluated according to Friedwald et al. [27] and Norbert [28] formulas, respectively by the following equations: LDL-C (mg/dl)=TC-(TG/5+HDL-C), vLDL (mg/
$\mathrm{dl})=\mathrm{TG} / 5$. The lipid peroxidation was determined colorimetrically as malondialdehyde (MDA) [29]. Hepatic xanthine oxidase (XO) and xanthine dehydrogenase $(\mathrm{XDH})$ were determined according to Kaminski and Jewezska [30]. Hepatic glutathione content (GSH) and the activity of superoxides dismutase (SOD) and catalase (CAT) were measured by the method of Gross et al. [31], Minami and Youshikawa [32] and Nie [33], respectively.

\section{Statistical analysis}

Statistical analyses were performed using computer program. Statistical Packages for Social Science (SPSS) [34] and values were compared to each other using one-way analysis of variance (ANOVA).

\section{Results}

Rosemary essential oils were analyzed by GC-MS chromatograms and the results revealed that the main components of the raw samples were camphor (20.85\%), caryophyllene (18.37\%), 1, 8-cineole $(14.49 \%)$, $\Delta$-Cadinene $(9.59 \%)$ and $\alpha$-Pinene $(8.46 \%)$. While, the main components of irradiated rosemary essential oil (10 kGy) were 1, 8-cineole (33.68\%), a-Terpinolen (22.63\%) and Borneol (7.88\%) (Table 1).

The activity of AST, ALT, ALP and GGT as well as the concentration of serum bilirubin for different animal groups were given in table 2. Oral administration of ethanol induced significant elevation in the activity of these liver enzymes and the level of total bilirubin as compared to the values of control at $\mathrm{P}<0.05$. Whereas, treatment of EtOH-rats with raw or irradiated rosemary showed a significant reduction in these enzymes activity and total bilirubin level as compared to ethanol administrated rats.

The mean values of serum TC, TG, LDL-C and vLDL-C were significantly increased, while the mean value of HDL-C was significantly

\begin{tabular}{|c|c|c|c|}
\hline \multirow[t]{2}{*}{ Compounds } & \multirow[t]{2}{*}{ RT(min) } & \multicolumn{2}{|c|}{ Constituents of essential oil } \\
\hline & & Raw & 10 kGy \\
\hline$\alpha$-Pinene & 5.204 & 8.46 & 2.40 \\
\hline B- Pinene & 5.338 & 0.64 & - \\
\hline 1,8-Cineol & 6.603 & 14.49 & 33.68 \\
\hline ү-Terpinene & 7.345 & 4.50 & 1.50 \\
\hline B-Terpineol & 8.403 & 0.30 & - \\
\hline$\alpha$-Terpinolen & 8.476 & 2.84 & 22.63 \\
\hline Camphor & 8.768 & 20.85 & - \\
\hline Borneol & 9.766 & 0.08 & 7.88 \\
\hline$\alpha$-Terpineol & 10.605 & 0.94 & - \\
\hline Verbenone & 11.031 & 2.90 & 1.40 \\
\hline Benzaldehyde & 11.687 & 1.35 & - \\
\hline Propanol & 11.858 & - & 0.51 \\
\hline Myrtanol & 12.052 & 0.64 & - \\
\hline Cinnannaldehyde & 12.332 & 0.91 & - \\
\hline Endobornyl & 12.478 & 0.46 & - \\
\hline Phenol & 12.575 & - & 0.56 \\
\hline Promecarb & 12.916 & 0.08 & 1.49 \\
\hline a-Copaene & 14.558 & - & 5.75 \\
\hline Caryophyllene & 14.777 & 18.37 & 6.32 \\
\hline$\alpha$-Humulene & 15.349 & 0.71 & 0.06 \\
\hline Naphthalene & 15.641 & 1.60 & 1.26 \\
\hline Delta-Cadinene & 17.027 & 9.59 & 0.97 \\
\hline $\begin{array}{l}\text { Caryophyllene } \\
\text { oxide }\end{array}$ & 17.721 & 2.70 & 1.03 \\
\hline Tau-Cadinol & 17.794 & 0.45 & 0.56 \\
\hline $\begin{array}{c}\text { Cyclopentaneace- } \\
\text { tic acid }\end{array}$ & 17.988 & - & 0.57 \\
\hline$\beta$-Elemene & 18.085 & 0.53 & - \\
\hline Caryophylla & 18.158 & - & 1.02 \\
\hline $\begin{array}{l}\text { Benzocyclohep- } \\
\text { tane }\end{array}$ & 19.995 & 0.80 & - \\
\hline Anymol & 20.081 & - & 1.81 \\
\hline a-Androst & 20.652 & 0.53 & 0.33 \\
\hline Unknown & 20.923 & 5.28 & 8.27 \\
\hline
\end{tabular}

Table 1: Effect of $y$-irradiation on constituents (\%) of rosemary essential oil. 
Citation: Hamzaa RG, El Shahat AN, Mekawey HMS. (2012) Modulating Efficiency of y-Irradiated Rosemary in Improving the Hepatic Antioxidant Status of Ethanol Administrated Rats. Biochem Anal Biochem 1:124. doi:10.4172/2161-1009.1000124

Page 3 of 6

\begin{tabular}{|c|c|c|c|c|}
\hline Parameters & I & II & III & IV \\
\hline AST $(\mathrm{U} / \mathrm{ml})$ & $25.87 \pm 1.74^{\mathrm{a}}$ & $49.43 \pm 2.93^{\mathrm{c}}$ & $31.38 \pm 2.29^{\mathrm{b}}$ & $30.89 \pm 2.29^{\mathrm{b}}$ \\
\hline ALT $(\mathrm{U} / \mathrm{ml})$ & $15.78 \pm 1.18^{\mathrm{a}}$ & $44.18 \pm 2.11^{\mathrm{c}}$ & $25.37 \pm 1.95^{\mathrm{b}}$ & $24.15 \pm 1.62^{\mathrm{b}}$ \\
\hline ALP $(\mathrm{U} / 100 \mathrm{ml})$ & $9.12 \pm 0.37^{\mathrm{a}}$ & $16.95 \pm 0.71^{\mathrm{c}}$ & $11.22 \pm 0.57^{\mathrm{b}}$ & $11.07 \pm 0.53^{\mathrm{b}}$ \\
\hline GGT $(\mathrm{U} / \mathrm{ml})$ & $3.38 \pm 0.27^{\mathrm{a}}$ & $6.09 \pm 0.44^{\mathrm{c}}$ & $4.51 \pm 0.47^{\mathrm{b}}$ & $4.42 \pm 0.39^{\mathrm{b}}$ \\
\hline Bilirubin(mg/dl) & $0.61 \pm 0.02^{\mathrm{a}}$ & $1.13 \pm 0.03^{\mathrm{c}}$ & $0.71 \pm 0.02^{\mathrm{b}}$ & $0.70 \pm 0.03^{\mathrm{b}}$ \\
\hline
\end{tabular}

Values are expressed as means \pm S.E. $(n=7)$.

Values in the same row with different superscripts are differing significantly at $P<0.05$.

Table 2: Effect of rosemary supplementation on hepatic markers in the serum of ethanol administered rats.

decreased in ethanol group compared to control group. EtOH-rats dietary supplemented with raw and $\gamma$-irradiated rosemary showed an obvious decrease in the mean values of serum TC, TG, LDL-C and vLDL-C associated with a noticeable increase in HDL-C concentration compared to ethanol group (Table 3).

Ethanol intake was associated with marked decrease in level of hepatic GSH content and the activity of XDH, SOD and CAT accompanied by significant increase in the values of MDA and XO activity. Treatment of rats with rosemary (raw and irradiated) following ethanol administration resulted in improvement in the activity of the antioxidant enzymes and elevation of GSH content as well as reduction of MDA and XO levels (Table 4).

\section{Discussion}

Excessive intake of alcohol causes severe damage to the liver, which may become cirrhotic. Rosemary constituents have a therapeutic potential in the treatment or prevention of bronchial asthma, spasmogenic disorders, diabetes mellitus, peptic ulcer, inflammatory diseases, hepatotoxicity, atherosclerosis, ischemic heart diseases, cataract, cancer and poor sperm motility [5,35-38].

From the results of this study, it could be observed that some essential oils were disappeared and some new components were appeared in irradiated rosemary as well as the values of other essential oils such as 1,8 -cineole and $\alpha$-Terpinolen were increased under the effect of $\gamma$-irradiation ( $10 \mathrm{kGy})$. These results were in agreement with Lee et al. [39] who found that radiation dose up to $10 \mathrm{kGy}$ resulted in appearance of new components (bicyclo, phenol and $\alpha$-Copaene) and disappearance of some components ( $\beta$-Terpineol, $\alpha$-Terpineol, benzaldehyde and camphene) in irradiated rosemary essential oil samples, in addition to the enhancement of antibacterial activity and of scavenging activity. Moreover, Pérez et al. [14] reported that sanitizing dry rosemary with gamma radiation gives rise to extracts with improved antioxidant properties which could be of use in the food and pharmaceutical industries.

The mechanism by which radiation induces changes in the volatile oil composition could presumably be due to the sensitivity of the components of the volatile oil, the changes in molecules configuration due to radiation, the changes resulted from the oxidation and hydroxylation of the aromatic rings of trepans and the possible degradation of some essential oil constituents during gamma irradiation as well as the radiolytic effect and possible production of free radicals [40].

1,8-cineole is one of important essential oil that has high antioxidant activity; thus the elevation of its value by $\gamma$-irradiation resulted in increasing the biological efficiency of $\gamma$-irradiated rosemary. Ciftci et al. [40] concluded that cineole showed antioxidant activity and eliminated oxidative stress induced by persistent environmental

\begin{tabular}{|c|c|c|c|c|}
\hline Parameters & I & II & III & IV \\
\hline TC $(\mathrm{mg} / \mathrm{dl})$ & $157.41 \pm 3.29^{\mathrm{a}}$ & $212.54 \pm 4.18^{\mathrm{c}}$ & $185.46 \pm 3.36^{\mathrm{b}}$ & $183.89 \pm 3.49^{\mathrm{b}}$ \\
\hline $\mathrm{TG}(\mathrm{mg} / \mathrm{dl})$ & $114.66 \pm 3.51^{\mathrm{a}}$ & $184.19 \pm 2.68^{\mathrm{c}}$ & $153.46 \pm 2.67^{\mathrm{b}}$ & $150.32 \pm 2.56^{\mathrm{b}}$ \\
\hline HDL-C $(\mathrm{mg} / \mathrm{dl})$ & $46.63 \pm 1.72^{\mathrm{a}}$ & $36.85 \pm 1.82^{\mathrm{c}}$ & $41.08 \pm 1.51^{\mathrm{b}}$ & $41.73 \pm 1.51^{\mathrm{b}}$ \\
\hline LDL-C $(\mathrm{mg} / \mathrm{dl}))$ & $87.85 \pm 2.57^{\mathrm{a}}$ & $138.85 \pm 2.02^{\mathrm{c}}$ & $113.69 \pm 2.15^{\mathrm{b}}$ & $112.10 \pm 2.37^{\mathrm{b}}$ \\
\hline VLDL-C $(\mathrm{mg} / \mathrm{dl})^{2}$ & $22.93 \pm 1.25^{\mathrm{a}}$ & $36.84 \pm 1.73^{\mathrm{c}}$ & $30.69 \pm 1.47^{\mathrm{b}}$ & $30.06 \pm 1.66^{\mathrm{b}}$ \\
\hline
\end{tabular}

Values are expressed as means \pm S.E. $(n=7)$

Values in the same row with different superscripts are differing significantly at $\mathrm{P}<0.05$.

Table 3: Effect of rosemary supplementation on serum lipid profile of ethanol administered rats.

\begin{tabular}{|c|c|c|c|c|}
\hline Parameters & I & II & III & IV \\
\hline MDA (n mol/ml) & $173.51 \pm 3.44^{\mathrm{a}}$ & $378.52 \pm 3.59^{\mathrm{c}}$ & $223.06 \pm 3.77^{\mathrm{b}}$ & $212.56 \pm 3.37^{\mathrm{b}}$ \\
\hline $\mathrm{XO}(\mathrm{mU} / \mathrm{mg}$ protein) & $2.23 \pm 0.06^{\mathrm{a}}$ & $3.56 \pm 0.07^{\mathrm{c}}$ & $2.51 \pm 0.04^{\mathrm{b}}$ & $2.44 \pm 0.04^{\mathrm{b}}$ \\
\hline $\mathrm{XDH}(\mathrm{mU} / \mathrm{mg}$ protein) & $3.13 \pm 0.18^{\mathrm{a}}$ & $1.72 \pm 0.11^{\mathrm{c}}$ & $2.77 \pm 0.18^{\mathrm{b}}$ & $2.86 \pm 0.16^{\mathrm{b}}$ \\
\hline $\mathrm{GSH}(\mathrm{mg} / \mathrm{g}$ tissue $)$ & $25.14 \pm 1.48^{\mathrm{a}}$ & $16.04 \pm 1.31^{\mathrm{c}}$ & $22.92 \pm 1.56^{\mathrm{b}}$ & $23.64 \pm 1.42^{\mathrm{b}}$ \\
\hline $\mathrm{SOD}(\mathrm{U} / \mathrm{mg}$ protein) & $45.07 \pm 2.25^{\mathrm{a}}$ & $34.92 \pm 2.55^{\mathrm{c}}$ & $41.28 \pm 1.85^{\mathrm{b}}$ & $42.41 \pm 1.73^{\mathrm{b}}$ \\
\hline $\mathrm{CAT}(\mathrm{U} / \mathrm{g}$ protein) & $3.44 \pm 0.05^{\mathrm{a}}$ & $1.83 \pm 0.03^{\mathrm{c}}$ & $2.89 \pm 0.04^{\mathrm{b}}$ & $2.93 \pm 0.05^{\mathrm{b}}$ \\
\hline
\end{tabular}

Values are expressed as means \pm S.E. $(n=7)$.

Values in the same row with different superscripts are differing significantly at $\mathrm{P}<0.05$

Table 4: Effect of rosemary supplementation on MDA, hepatic xanthine oxidoreductase system (XO and XDH), GSH, SOD and CAT of ethanol administered rats.

pollutant (2,3,7,8-Tetrachlorodibenzodioxin) in rats in a timedependent manner. Also, Santos et al. [41] reported that the hepatic necrosis induced by D-galactosamine/lipopolysaccharide (GalN/LPS) was greatly reduced by 1,8 cineole treatment.

In this study, alcohol intake increased the mean values of liver enzymes (ALT, AST, ALP and $\gamma \mathrm{GT}$ ) and total bilirubin. Rajakrishnan and Menon [42] indicated that exposure of hepatocytes to ethanol alters the membrane structure and functions by increasing the leakage of enzymes into the circulation. Das et al. [43] reported that excess alcohol consumption has been linked with altered liver metabolism and liver damage, with leakage of cytoplasmic liver enzyme $\gamma \mathrm{GT}$ into blood. Also, Hussein et al. [4] observed a significant increase in the activity of serum liver enzymes ALT, AST and $\gamma$ GT in ethanol group compare to control group.

However, ethanol administrated-rats received either raw or $\gamma$-irradiated rosemary for 4 weeks had a significant amelioration in the activity of ALT, AST, ALP and $\gamma$ GT and the concentration of total bilirubin compared to ethanol group. These finding are in accordance with the results of Fahim et al. [44], who reported that administration of rosemary extract $(150 \mathrm{mg} / \mathrm{kg}$ body weight) to rats for 3 weeks produced pronounced hepatoprotective effect. Also, Aruoma et al. [45] exhibited the hepatoprotective properties of rosemary via the retardation of oxidative degradation of lipids. It was also previously proved that rosemarinic and carnosic acids contain mixtures of natural antioxidants inhibited LDL oxidation and have the ability to prevent the deposition of triglycerides in the liver [46-48]. Moreover, Abd ElGhany et al. [49] obtained that the inclusion of rosemary powder and rosemary extract to the liver injured rats ameliorated liver enzyme activities compared with CCl4-rats.

Several studies demonstrated that alcohol intake is associated with changes in serum lipid concentrations and whole-body lipid balance $[4,50]$. In the present study, there was a significant increase in the mean values of serum TC, TG, LDL-C and vLDL-C accompanied by a significant decrease in the mean value of serum HDL-C in ethanol group. These results were in agreement with Kumar et al. 
Citation: Hamzaa RG, El Shahat AN, Mekawey HMS. (2012) Modulating Efficiency of y-Irradiated Rosemary in Improving the Hepatic Antioxidant Status of Ethanol Administrated Rats. Biochem Anal Biochem 1:124. doi:10.4172/2161-1009.1000124

[51] who reported that ethanol blocks fat oxidation and favours fat accumulation. The accumulation of fat in liver acts as a stimulus for the secretion of lipoproteins into the blood stream and the development of hyperlipidemia.

Administration of raw and $\gamma$-irradiated rosemary powder after ethanol intake caused significant declines in the lipid contents associated with an obvious increase in HDL-C concentration. Aljamal et al. [52] showed that the administration of rosemary decreased the level of cholesterol, triglycerides, LDL, and increased HDL in diabetic rats. Also, the authors indicated that the administration of rosemary shows better lipid profile in both normal and diabetic rats. Moreover, it seemed that rosemary possess a variety of important constituents such as caffeic acid and rosmarinic acid that have antioxidant effect and hypolipidemic potential. This may be an indication of progressive metabolic control of rosemary on mechanisms involved in elimination of the lipids from the body [5]. In addition to a well documented role in reverse cholesterol transport, HDL-cholesterol has been recognized to have several other important cardio protective properties including the ability to protect LDL from oxidative modification [53].

It was found that the inflammatory reactions and oxidative stress play a major role in alcohol hepatotoxicity [54]. In this investigation, there was a significant increase in MDA concentration accompanied by conversion of hepatic $\mathrm{XDH}$ to $\mathrm{XO}$ as a result of ethanol administration. Das and Vasudevan $[55,56]$ observed increased lipid peroxidation with ethanol in their dose dependent studies. During ethanol metabolism, potentially dangerous byproducts are generated including reactive oxygen species (ROS) [2] which react with membrane lipids and cause lipid peroxidation leading to cell death [57]. Metabolism of ethanol to acetaldehyde leads to the conversion of a portion of tissue xanthine dehydrogenase $(\mathrm{XDH})$ to xanthine oxidase $(\mathrm{XO})$ due to an increase in cellular $\mathrm{NADH}$ as a result of ethanol oxidation with subsequent production of superoxide anion radicals [58]

Also, the present study revealed that the level of GSH content and the activity of SOD and CAT were significantly decreased in the liver of ethanol-administrated rats. In agreement, Masalkar and Abhang [59] found a decrease in antioxidant statue in alcoholic patients and showed that increased generation of free radicals and deficiencies of dietary antioxidants can be important etiological factor in alcoholic liver disease. Husain and Somani [60] reported a significant decrease in GSH content with EtOH treatment $(1.6 \mathrm{~g} / \mathrm{kg})$ in hepatic tissue of rats. Also, Das and Vasudevan [57] in their alcohol dose dependent studies observed a significant decrease in GSH content in the hepatic tissue of rats. The decrease in GSH content after ethanol intoxication reflects the impaired conversion of glutathione of oxidized form to reduced form [61] thus alters the GSH/GSSG ratio. The increase in GSH/GSSG ratio in the liver of EtOH fed rats and inhibition of glutathione reductase are indicative of ethanol induced oxidative stress in the liver leading to the decreased antioxidant enzyme capacity [60].

The decrease in SOD activity in blood was reported by Husain and Somani [60] and in hepatic tissue [62] has also been reported during EtOH intoxication. The over-production of superoxide radicals due to EtOH intoxication implies low activity of SOD under ethanol induced oxidative stress in the hepatic tissue. The significant decrease in SOD activity due to ethanol administration indicates inefficient scavenging of reactive oxygen species (ROS) which might be implicated to oxidative inactivation of enzymes [63]. Moreover, Bindu et al. [64] reported a significant decrease in CAT activity with $4 \mathrm{~g} / \mathrm{kg}$ EtOH treatment for a period of 50 days in rats. Das and Vasudevan [56] found a significant decrease in CAT activity in the hepatic tissue of rats treated with $2 \mathrm{~g} / \mathrm{kg}$ $\mathrm{EtOH}$ for a period of 4 weeks.

In this study, inclusion of rosemary powder (raw or $\gamma$-irradiated) to EtOH-rats provided anti-lipoperoxidant activity, as it reduced the formation of MDA and significantly decreased in XO activity associated with an obvious elevation in GSH content and the activity of XDH, SOD and CAT in liver. Bakirel et al. [65] found that long-term treatment of diabetes with the highest dose of the Rosmarinus officinalis extract had reversed the activities of the antioxidant enzymes, which might be due to decreased oxidative stress as evidenced by decreased lipid peroxidation. The authors reported that the Rosmarinus officinalis extract due to presence of several bioactive antioxidant principles and their synergistic properties may be caused an improving effect in antioxidant status. Moreover, Khalil et al. [66] observed a significant decrease in oxidative stress markers including serum TBARS and nitric oxide (NO). Serum enzymatic (glutathione transferase (GST), catalase (CAT), glutathione peroxidase (GPx) and non enzymatic antioxidants (vitamin $\mathrm{C}$ and reduced glutathione) were found to be increased by the administration of Rosmarinus officinalis.

\section{Conclusion}

In conclusion, the data obtained in the present investigation confirmed the well known effect of ethanol in decreasing the antioxidant enzymes in liver tissues which may be due to the production of high amount of ROS. These effects were reversed by the treatment of rats with $1 \%$ of dietary $\gamma$-irradiated rosemary suggesting that rosemary has the potential to inhibit lipid peroxidation and improve the antioxidant status in rat liver. Hence, rosemary might be utilized as a nutritional supplement or a functional food component against liver injury. Moreover, the present data revealed that radiation dose (10 kGy) can improve the quality of rosemary essential oil by increasing the value of some essential oil such as 1,8-cineole.

\section{Acknowledgement}

Authors are grateful to their colleague at the food irradiation department Safaa Afifi Mohamed for her help and support to carry out this work.

\section{References}

1. Sarkar MK, Sarkar K, Bhattacharjee R, Chatteriee M Sil PC (2005) Curative role of the aqueous extract of the herb, Phyllanthus niruri, against nimesulide induced oxidative stress in murine liver. Biomedical Research 16: 171-176.

2. Lieber CS (2004) Alcoholic fatty liver: its pathogenesis and mechanism of progression to inflammation and fibrosis. Alcohol 34: 9-19.

3. Augustyniak A, Waszkiewicz E, Skrzydlewska E (2005) Preventive action of green tea from changes in the liver antioxidant abilities of different aged rats intoxicated with ethanol. Nutrition 21: 925-932.

4. Hussein J, Salah A, Oraby F, El-Deen A N, El-Khayat Z (2010) Antihepatotoxic Effect of Eruca Sativa Extracts on Alcohol Induced Liver Injury in Rats. Journal of American Science 6: 381-389

5. Al-Jamal A and Alqadi T (2011) Effects of Rosemary (Rosmarinus officinalis) on Lipid Profile of Diabetic Rats. Jordan Journal of Biological Sciences 4: 199-204.

6. Cakilcioglu U, Türkoglu I (2007) Plants used to lower blood sugar in Elazig Central District, In: I. International Medicinal and Aromatic Plants Conference on Culinary Herbs. Acta Horticulturae 826: 97-104

7. Ugulu I, Baslar S, Yorek N, Dogan Y (2009) The investigation and quantitative ethnobotanical evaluation of medicinal plants used around Izmir province, Turkey J Med Plants Res 3: 345-367.

8. Tetik F (2011) A research on the ethnobotanical valued plants in Malatya province. Yüksek lisans Tezi. Firat Üniversitesi, Fen Bilimleri Enstitüsü, Elazig.

9. Bieski IG, Rios Santos F, de Oliveira RM, Espinosa MM, Macedo M, et al. (2012) Ethnopharmacology of medicinal plants of the pantanal region (mato grosso, Brazil). Evid Based Complement Alternat Med. 
Citation: Hamzaa RG, El Shahat AN, Mekawey HMS. (2012) Modulating Efficiency of y-Irradiated Rosemary in Improving the Hepatic Antioxidant Status of Ethanol Administrated Rats. Biochem Anal Biochem 1:124. doi:10.4172/2161-1009.1000124

10. Tavaafi M, Ahmadvand $\mathrm{H}$, Tamjidipoor A (2011) Rosmarinic acid ameliorates diabetic nephropathy in uninephrectomized diabetic rats. Iran J Basic Med Sci 14: $275-283$

11. Alnahdi HS (2012) Effect of Rosmarinus officinalis Extract on some Cardiac Enzymes of Streptozotocin-induced Diabetic Rats. J of Health Sci 2: 33-37.

12. Legnani PP, Leoni E, Righi F, Zarabini LA (2001) Effect of microwave heating and gamma irradiation on microbiological quality of spices and herbs. Italian Journal of Food Science 3: 337-345

13. IAEA (2006) Database on approvals for irradiated food. Food and environmental protection newsletter Suppl 21-59.

14. Pérez MB, Calderon NL, Croci CA (2007) Radiation-induced enhancement of antioxidant activity in extracts of rosemary (Rosmarinus officinalis L.). Food Chem 104: 585-592.

15. Koseki PM, Villavicencio AL, Brito MS, Nahme LC, Sebastião KI, et al. (2002) Effects of irradiation in medicinal and eatable herbs. Radiation Physics and Chemistry 63: 681-684

16. Calucci L, Pinzino C, Zandomeneghi M, Capocchi A, Ghiringhelli S, et al. (2003) Effects of $y$-irradiation on the free radical and antioxidant contents in nine aromatic herbs and spices. J Agric Food Chem 51: 927-934.

17. El-Beltagi HS, Ahmed OK, El-Desouky W (2011) Effect of low doses g-irradiation on oxidative stress and secondary metabolites production of rosemary (Rosmarinus officinalis L.) callus culture. Radiation Physics and Chemistry 80: 968-976

18. Guenther E (1961) "The essential oils". (4thedn), d. D. Van Nostrand Company Inc., Princeton, New Jersey, Toronto, New York, London 460.

19. Adams RP (1995) Identification of essential oil components by gas chromatography and mass spectrometry. (4thedn), Allured Publ. Corp. Carol Stream, USA 310

20. Reitman S, Frankel S (1957) A colorimetric method for the determination of serum glutamic oxalacetic and glutamic pyruvic transaminases. Am J Clin Pathol 28: 56-63.

21. Rosalk SB (1657) In advances clinical chemistry. Academic Press Chap 17: 53.

22. Kind PR, King EJ (1954) Estimation of plasma phosphatase by determination of hydrolysed phenol with amino-antipyrine. J Clin Pathol 7: 322-326.

23. Malloy HT, Evelyn KA (1937) The determination of bilirubin with the photoelectric colorimeter. J Biol Chem 119: 481-490

24. Allain CC, Poon LS, Chan CS, Richmond W, Fu PC (1974) Enzymatic determination of total serum cholesterol. Clin Chem 20: 470-475.

25. Fossati P, Prencipe $L$ (1982) Serum triglycerides determined colorimetrically with an enzyme that produces hydrogen peroxide. Clin Chem 28: 2077-2080.

26. Demacker P, Vos-janssen H, Hifman A, Vants Lear A, Jansen A (1980) Measurement of high density lipoprotein cholesterol in serum. Clin Chem 26 1780.

27. Friedewald WT, Levy RI, Fredrickson DS (1972) Estimation of the concentration of low-density lipoprotein cholesterol in plasma, without use of the preparative ultracentrifuge. Clin Chem 18: 499-502.

28. Norbert WT (1995) Clinical Guide to Laboratory Tests. (3rdedn), Saunders W.B. Company, Philadelphia.

29. Yoshioka T, Kawada K, Shimada T, Mori M (1979) Lipid peroxidation in materna and cord blood and protective mechanism against activated-oxygen toxicity in the blood. Am J Obstet Gynecol 135: 372-376.

30. Kaminski ZW, Jezewska MM (1979) Intermediate dehydrogenase-oxidase form of xanthine oxidoreductase in rat liver. Biochem J 181: 177-182.

31. Gross RT, Bracci R, Rudolph N, Schroeder E, Kochen JA (1967) Hydrogen peroxide toxicity and detoxification in the erythrocytes of newborn infants. Blood 29: 481-493

32. Minami M, Yoshikawa H (1979) A simplified assay method of superoxide dismutase activity for clinical use. Clin Chim Acta 92: 337-342.

33. Nie NH (1998) SPSS: Statistical Package for Social Science. McGraw-Hill, New York.

34. Osakabe N, Yasuda A, Natsume M, Yoshikawa T (2004) Rosmarinic acid inhibits epidermal inflammatory responses: anticarcinogenic effect of Perilla frutescens extract in the murine two-stage skin model. Carcinogenesis 25: 549557.
35. Masuda T, Inaba Y, Maekawa T, Takeda Y, Tamura H, et al. (2002) Recovery mechanism of the antioxidant activity from carnosic acid quinone, an oxidized sage and rosemary antioxidant. J Agric Food Chem 50: 5863-5869.

36. Sotelo-Félix JI, Martinez-Fong D, Muriel De la Torre P (2002) Protective effect of carnosol on $\mathrm{CCl}(4)$-induced acute liver damage in rats. Eur J Gastroentero Hepatol 14: 1001-1006.

37. al-Sereiti MR, Abu-Amer KM, Sen P (1999) Pharmacology of rosemary (Rosmarinus officinalis Linn.) and its therapeutic potentials. Indian J Exp Bio 37: $124-130$

38. Abdeldaiem MH, Mohamed HG, Abdel-Khalek HH (2009) Antimicrobial and antioxidant activities of rosemary essential oil treated by gamma irradiation. $J$ Rad Res Appl Sci 2: 819-837.

39. Lee NY, Jo C, Sohn SH, Kim JK, Byun MW (2006) Effects of gamma irradiation on the biological activity of green tea byproduct extracts and a comparison with green tea leaf extracts. J Food Sci 71: C269-C274

40. Ciftci O, Ozdemir I, Tanyildizi S, Yildiz S, Oguzturk H (2011) Antioxidative effects of curcumin, $\beta$-myrcene and 1,8-cineole against 2,3,7,8-tetrachlorodibenzo-pdioxin-induced oxidative stress in rats liver. Toxicol Ind Health 27: 447-453.

41. Santos FA, Silva RM, Tomé AR, Rao VS, Pompeu MM, et al. (2001) 1,8-cineole protects against liver failure in an in-vivo murine model of endotoxemic shock. J Pharm Pharmacol 53: 505-511.

42. Akrishnan VR, Menon VP (2001) Potential role of antioxidants during ethanolinduced changes in the fatty acid composition and arachidonic acid metabolites in male Wistar rats. Cell Biol Toxicol 17: 11-22.

43. Das D, Mukherjee MM, Das AS, Mitra C (2005) Aqueous extract of black tea (Camellia sinensis) prevents chronic ethanol toxicity. Curr Sci 88: 952-961.

44. Fahim FA, Esmat AY, Fadel HM, Hassan KF (1999) Allied studies on the effect of Rosmarinus officinalis L. on experimental hepatotoxicity and mutagenesis. Int J Food Sci Nutr 50: 413-427.

45. Aruoma OI, Spencer JP, Rossi R, Aeschbach R, Khan A, et al. (1996) An evaluation of the antioxidant and antiviral action of extracts of rosemary and Provençal herbs. Food Chem Toxicol 34: 449-456.

46. Asai A, Nakagawa K, Miyazawa T (1999) Antioxidative effects of turmeric rosemary and capsicum extracts on membrane phospholipid peroxidation and liver lipid metabolism in mice. Biosci Biotechnol Biochem 63: 2118-2122.

47. Fuhrman B, Volkova N, Rosenblat M, Aviram M (2000) Lycopene synergistically inhibits LDL oxidation in combination with vitamin $\mathrm{E}$, glabridin, rosmarinic acid, carnosic acid, or garlic. Antioxid Redox Signal 2: 491-506.

48. Zeng HH, Tu PF, Zhou K, Wang H, Wang BH, et al. (2001) Antioxidant properties of phenolic diterpenes from Rosmarinus officinalis. Acta Pharmaco Sin 22: 1094-1098.

49. Abd El-Ghany MA, Motawee MM, El-Kewawy HEM (2012) Biological effects of yoghurt with rosemary on injured liver rats. Australian $\mathrm{J}$ of Basic and Applied Sci 6: 525-532.

50. Siler SQ, Neese RA, Hellerstein MK (1999) De novo lipogenesis, lipid kinetics, and whole-body lipid balances in humans after acute alcohol consumption. Am $\mathrm{J}$ Clin Nutr 70: 928-936.

51. Kumar RS, Ponmozhi M, Viswanathan P, Nalini N (2002) Effect of Cassia auriculata leaf extract on lipids in rats with alcoholic liver injury. Asia Pac J Clin Nutr 11: 157-163.

52. Aljamal A, Ibrahim A, Al-Fararjeh M A, Alqadi T (2012) Effects of rosemary on lipid profile in diabetic rats. African J of Plant Sci 6: 222-225.

53. Nofer JR, Kehrel B, Fobker M, Levkau B, Assmann G, et al. (2002) HDL and arteriosclerosis: beyond reverse cholesterol transport. Atherosclerosis 161 : $1-16$.

54. Albano E (2002) Free radicals and alcohol-induced liver injury. In "Ethanol and the Liver", Sherman CDIN, Preedy VR and Watson RR (eds.).London: Taylor and Francis 153-190.

55. Mallikarjuna K, Nishanth K, Hou CW, Kuo CH, Reddy KS (2009) Alcohol 43 $59-64$

56. Das SK, Vasudevan DM (2005) Effect of ethanol on liver antioxidant defense systems: Adose dependent study. Indian J Clin Biochem 20: 80-84.

57. Das SK, Vasudevan DM (2005) Biochemical diagnosis of alcoholism. Indian J Clin Biochem 20: 35-42. 
Citation: Hamzaa RG, El Shahat AN, Mekawey HMS. (2012) Modulating Efficiency of Y-Irradiated Rosemary in Improving the Hepatic Antioxidant Status of Ethanol Administrated Rats. Biochem Anal Biochem 1:124. doi:10.4172/2161-1009.1000124

Page 6 of 6

58. Umamaheswari M, Asokkumar K, Umamageswari N, Sivashanmugam $T$ Subhadradevi V (2012) Protective effect of the leaves of Vitex negundo against ethanol-induced cerebral oxidative stress in rats. Tanzan J Health Res 14: 1-11.

59. Masalkar PD, Abhang SA (2005) Oxidative stress and antioxidant status in patients with alcoholic liver disease. Clin Chim Acta 355: 61-65.

60. Husain K, Somani SMJ (1997) Interaction of Exercise Training and Chronic Ethanol Ingestion on Hepatic and Plasma Antioxidant System in Rat. Appl Toxicol 17: 189-194.

61. Dinu V, Zamfir O (1991) Oxidative stress in ethanol intoxicated rats. Rev Roum Physiol 28: 63-67.

62. Mahendran P, Shyamala Devi CS (2001) The modulating effect of Garcinia cambogia extract on ethanol induced peroxidative damage in rats. Indian $\mathrm{J}$ Pharmacol 33: 87-91.
63. Pigeolet E, Corbisier P, Houbion A, Lambert D, Michiels C, et al. (1990) Glutathione peroxidase, superoxide dismutase and catalase inactivation by peroxide and oxygen derived radicals. Mechanisms of Ageing and Development 51: $283-297$

64. Bindu MP, Sreekant KS, Annamali PT, Augusti KT (2002) Effect of S-allile cysteine sulphoxide on lipid metabolism and free radical scavenges in alcohol fed rats. Curr Sci 82: 628-631.

65. Bakirel T, Bakirel U, Keles OU, Ulgen SG, Yardibi H (2008) In vivo assessment of antidiabetic and antioxidant activities of rosemary (Rosmarinus officinalis) in alloxan-diabetic rabbits. J Ethnopharmacol 116: 64-73.

66. Khalil OA, Ramadan KS, Danial EN, Alnahdi HS, Ayaz NO (2012) Antidiabetic activity of Rosmarinus officinalis and its relationship with the antioxidant property. African Journal of Pharmacy and Pharmacology 6: 1031-1036. 